\title{
Engaging Undergraduates to Solve Global Health Challenges: A New Approach Based on Bioengineering Design
}

\author{
Maria Oden, ${ }^{1}$ Yvette Mirabal, ${ }^{1}$ Marc Epstein, ${ }^{2}$ and Rebecca Richards-Kortum ${ }^{1}$ \\ ${ }^{1}$ Department of Bioengineering MS 142, Rice University, 6100 Main Street, Biosciences Research Collaborative Suite 135, \\ Houston, TX 77005, USA; and ${ }^{2}$ Jesse H. Jones Graduate School of Management, Rice University, P.O. Box 2932, Houston, \\ TX 77252-2930, USA
}

(Received 5 February 2010; accepted 1 April 2010; published online 13 April 2010)

Associate Editor Scott I. Simon oversaw the review of this article.

\begin{abstract}
Recent reports have highlighted the need for educational programs to prepare students for careers developing and disseminating new interventions that improve global public health. Because of its multi-disciplinary, design-centered nature, the field of Biomedical Engineering can play an important role in meeting this challenge. This article describes a new program at Rice University to give undergraduate students from all disciplines a broad background in bioengineering and global health and provides an initial assessment of program impact. Working in partnership with health care providers in developing countries, students in the Beyond Traditional Borders (BTB) initiative learn about health challenges of the poor and put this knowledge to work immediately, using the engineering design process as a framework to formulate solutions to complex global health challenges. Beginning with a freshman design project and continuing through a capstone senior design course, the BTB curriculum uses challenges provided by partners in the developing world to teach students to integrate perspectives from multiple disciplines, and to develop leadership, communication, and teamwork skills. Exceptional students implement their designs under the guidance of clinicians through summer international internships. Since 2006, 333 students have designed more than 40 technologies and educational programs; 28 have been implemented in sub-Saharan Africa, Latin America, the Caribbean, southeast Asia, and the United States. More than 18,000 people have benefited from these designs. $95 \%$ of alumni who completed an international internship reported that participation in the program changed or strengthened their career plans to include a focus on global health medicine, research, and/or policy. Empowering students to use bioengineering design to address real problems is an effective way to teach the new generation of leaders needed to solve global health challenges.
\end{abstract}

Keywords-Design, Healthcare technology, International internship.

Address correspondence to Rebecca Richards-Kortum, Department of Bioengineering MS 142, Rice University, 6100 Main Street, Biosciences Research Collaborative Suite 135, Houston, TX 77005, USA. Electronic mail: rkortum@rice.edu

\section{INTRODUCTION}

While the past century has been marked by extraordinary advances in health, not all of the world's citizens have benefited from this progress. ${ }^{10}$ There are dramatic differences in health, linked to social disadvantage, both between and within countries. ${ }^{5}$ Ironically, most disparities in health occur as a result of preventable diseases. A recent policy forum ${ }^{12}$ examined why it is so challenging to implement what we already know about disease prevention, particularly in poor communities. Madon et al. conclude that closing this "implementation gap" requires a new generation of researchers, who can collaborate with governments, nongovernmental organizations, and communities to develop and implement sustainable solutions to improve health.

A number of new, multi-disciplinary educational programs have been developed to meet this important need. Graduate programs in public health are debating the appropriate balance between creating new knowledge and applying existing knowledge to improve the lives of the world's poor and marginalized, ${ }^{19}$ with important movements emerging to integrate community experiences together with classroom activities. ${ }^{16}$ During the past 20 years, the proportion of US and Canadian medical students participating in international electives has doubled to more than $20 \%$ of students; recent surveys indicate that there is an increasing, but unmet, student demand for global health training. ${ }^{9,15}$ Exposing medical students to global health issues has important benefits, including greater cultural understanding, stronger motivation to pursue future international health work, and better understanding of public health and the socioeconomic influences on health. ${ }^{6,9}$

The majority of public and global health training programs focus on the graduate and post-graduate 
levels, educating students who have already chosen to specialize in science, medicine or health policy. To solve global health disparities, it is imperative to develop future leaders across a broader range of disciplines, including engineering, economics, political science, and sociology. Crossing the implementation gap will require leaders who can focus not only on how to design the best technology, but also on how to put that technology to work, and who are comfortable thinking and working in new cultural and economic environments. ${ }^{8,12}$ The undergraduate experience presents a unique opportunity to inspire and educate students from many disciplines to address these important challenges. In the 2003 report "Who Will Keep the Public Healthy?," the US Institute of Medicine called for all undergraduates to have access to education in public health. ${ }^{7}$ A number of novel undergraduate programs are emerging to fill this need. ${ }^{2,18}$

\section{BIOMEDICAL ENGINEERING-A UNIQUE FRAMEWORK FOR UNDERGRADUATE PUBLIC HEALTH EDUCATION}

The process of bioengineering design - using science to solve biomedical problems in the face of constraints - provides a broad and unique context in which to approach undergraduate public health education. Project-based undergraduate activities can bring together students from diverse backgrounds in multi-disciplinary teams. Engaging students in solving real problems enhances students' understanding of course relevance, and increases student volunteerism. ${ }^{3,4}$ Several new undergraduate programs are engaging undergraduate engineering students in designing and implementing technology solutions to global health challenges. ${ }^{1,13}$

Rice University has used the engineering design framework as the basis for an innovative, interdisciplinary program in global health technologies. The program, known as Beyond Traditional Borders (BTB) ${ }^{20}$ is open to students from all disciplines; students use the process of bioengineering design to develop, evaluate, and disseminate multi-disciplinary solutions to global health challenges. Students learn about the epidemiology and pathophysiology of important diseases, as well as the numerous economic, cultural, political, social, and geographic factors that contribute to poor health around the world. Core courses teach the formalized engineering design process and allow students to use this process to formulate solutions to real global health problems that are increasingly complex as they progress through the program. One of the core principles of the program is that sustainable solutions to the global challenges of health and poverty require collaboration across disciplines and input from the affected community, both in terms of defining the problem and creating the solution. Therefore, global health design challenges are provided to the program by clinicians, nurses, and other health-care workers who work in low resource settings. These valuable mentors provide guidance and feedback to the teams throughout the design process. Students travel to developing countries to implement their solutions through summer international internships. Beginning with a freshman-level design project and continuing through a year-long capstone senior design course taught in conjunction with bioengineering senior design, this progression emphasizes how science and technology can solve real-world health problems, and helps students to develop the leadership skills necessary to implement such solutions. Students who complete the sequence of courses are awarded a minor in Global Health Technologies. Table 1 summarizes the courses in the minor and provides an overview of the desired learning outcomes associated with each course.

In project-based courses, students work in interdisciplinary teams to develop solutions to challenges provided by clinical or educational partners in the developing world. These advisors, who routinely confront these challenges in their professional lives, work closely with student teams to ensure that the students understand the problem and design constraints. Following the engineering design process (Fig. 1), students specify design requirements, brainstorm possible solutions, evaluate whether these solutions meet design specifications, and refine solutions to their assigned problem. Teams carry out research to document existing solutions and their limitations, conceive of new designs, and construct and test prototype solutions. Throughout this process, students must take into account ethical and cultural considerations, as well as economic and infrastructural limitations. Students learn to consider the diverse factors that determine the success or failure of their solution and to take advantage of one another's expertise, because successful interventions must integrate advances in science, engineering, business, sociology, anthropology, and many other disciplines. Students learn to think creatively and comprehensively not only about their designs, but also about how their designs can be brought to market in resource-poor settings. The result is that students directly experience how science and engineering are utilized as powerful tools to improve health and eliminate poverty.

Each team of students is paired with local mentors from the site where the challenge originated. Depending upon the project, mentors are physicians, nurses, engineers, educators, policy makers, or public health 
TABLE 1. Description of global health technologies curriculum.

Student selection criteria:

- The program is open to students in all majors; any student at the university is eligible to begin the course sequence

- To enroll in higher level courses, students must declare their intent to obtain a minor in global health technologies

Learning outcomes of the global health technologies program:

- Students will learn to solve real global health challenges using the engineering design process

- Students will learn that solutions to these challenges require an interdisciplinary approach that considers the technical as well as the social and public policy issues surrounding the problem

\begin{tabular}{|c|c|c|c|}
\hline \multicolumn{4}{|c|}{ Global health technologies courses and learning outcomes } \\
\hline Course name & Faculty & Course description & Learning outcomes \\
\hline $\begin{array}{l}\text { Bioengineering \& World } \\
\text { Health }\end{array}$ & Bioengineering & $\begin{array}{l}\text { This course is structured around four ques- } \\
\text { tions } \\
\text { (1) What are the problems in health today, \& } \\
\text { how these differ in developing \& devel- } \\
\text { oped countries? } \\
\text { (2) Who pays to solve problems in health } \\
\text { care? } \\
\text { (3) How can we use technology to solve } \\
\text { world-health problems? } \\
\text { (4) How do technologies move from bench to } \\
\text { bedside? }\end{array}$ & $\begin{array}{l}\text { Working knowledge of: Physiology \& epide- } \\
\text { miology of the major global health prob- } \\
\text { lems; global variations in health systems; } \\
\text { the engineering method to develop \& } \\
\text { assess new medical technologies; legal } \\
\text { and ethical issues regarding biomedical } \\
\text { research and technology dissemination }\end{array}$ \\
\hline $\begin{array}{l}\text { Appropriate Design for } \\
\text { Global Health }\end{array}$ & Bioengineering & $\begin{array}{l}\text { A semester long introductory design course } \\
\text { where multi-disciplinary teams of stu- } \\
\text { dents from different disciplines work } \\
\text { together to design solutions to a global } \\
\text { health challenge contributed by an inter- } \\
\text { national partner }\end{array}$ & $\begin{array}{l}\text { Working knowledge of: Appropriate technol- } \\
\text { ogies; engineering design process; mod- } \\
\text { els of technology dissemination in } \\
\text { developing countries }\end{array}$ \\
\hline Medical Sociology & Sociology & $\begin{array}{l}\text { Course explores the relationship between } \\
\text { social factors and health, illness, and } \\
\text { mortality }\end{array}$ & $\begin{array}{l}\text { Working knowledge of: Social \& cultural } \\
\text { determinants of health; ethics of concep- } \\
\text { tion, birth, death }\end{array}$ \\
\hline \multicolumn{4}{|l|}{-or- } \\
\hline $\begin{array}{l}\text { Human Factors \& } \\
\text { Ergonomics }\end{array}$ & Psychology & $\begin{array}{l}\text { Application of principles of psychology \& } \\
\text { human performance to the design of } \\
\text { modern systems }\end{array}$ & $\begin{array}{l}\text { Design of physical \& computer systems to } \\
\text { accommodate physical, perceptual and } \\
\text { cognitive limitations of users }\end{array}$ \\
\hline \multicolumn{4}{|c|}{ 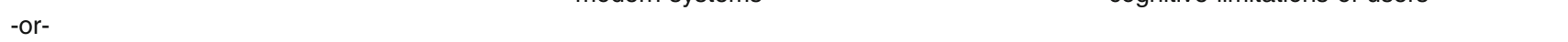 } \\
\hline $\begin{array}{l}\text { Metabolic Engineering } \\
\text { for Global Health }\end{array}$ & $\begin{array}{c}\text { Biochemistry \& } \\
\text { Cell Biology }\end{array}$ & $\begin{array}{l}\text { Course addresses problems in global health } \\
\text { that can be addressed by metabolic } \\
\text { engineering technologies applied to } \\
\text { nutrition, pharmaceutical \& public health } \\
\text { problems }\end{array}$ & $\begin{array}{l}\text { Biochemical pathways; molecular biology } \\
\text { tools and genetic engineering for ME; } \\
\text { nutritional molecules; \& pharmaceuticals } \\
\text { for global health }\end{array}$ \\
\hline $\begin{array}{l}\text { Global Health Design } \\
\text { Challenges I }\end{array}$ & Bioengineering & $\begin{array}{l}\text { A year-long capstone design course where } \\
\text { multi-disciplinary teams, mentored by }\end{array}$ & $\begin{array}{l}\text { Working knowledge of: The fundamentals of } \\
\text { the research and design process; devel- }\end{array}$ \\
\hline $\begin{array}{l}\text { Global Health Design } \\
\text { Challenges II }\end{array}$ & Bioengineering & $\begin{array}{l}\text { interdisciplinary faculty teams, work to } \\
\text { develop a solution to a real-world inter- } \\
\text { national health challenge. New technolo- } \\
\text { gies are developed with reference to both } \\
\text { the societal and scientific issues associ- } \\
\text { ated with the global health challenge, } \\
\text { such as design for universal use }\end{array}$ & $\begin{array}{l}\text { oping a design from initial concept, to } \\
\text { basic research, to prototype and finally to } \\
\text { device evaluation; \& the design and reg- } \\
\text { ulation of medical devices and biotech- } \\
\text { nology innovations }\end{array}$ \\
\hline $\begin{array}{l}\text { Humanities/Social } \\
\text { Sciences Elective }\end{array}$ & Various & $\begin{array}{l}\text { Students select from elective options in the } \\
\text { following areas: Anthropology, Econom- } \\
\text { ics, English, Kinesiology, History, Philos- } \\
\text { ophy, Psychology, Religious Studies, } \\
\text { Sociology }\end{array}$ & $\begin{array}{l}\text { Students select a course that will broaden } \\
\text { their perspective on global health issues } \\
\text { from a specific humanities or social sci- } \\
\text { ences point of view }\end{array}$ \\
\hline $\begin{array}{l}\text { Science/Engineering } \\
\text { Elective }\end{array}$ & Various & $\begin{array}{l}\text { Students select from elective options in the } \\
\text { following areas: Bioengineering, Bio- } \\
\text { chemistry \& Cell Biology, Civil \& Envi- } \\
\text { ronmental Engineering, Chemistry, } \\
\text { Environmental Studies, Statistics }\end{array}$ & $\begin{array}{l}\text { Students select a course that will broaden } \\
\text { their perspective on global health issues } \\
\text { from a specific science or engineering } \\
\text { point of view }\end{array}$ \\
\hline
\end{tabular}




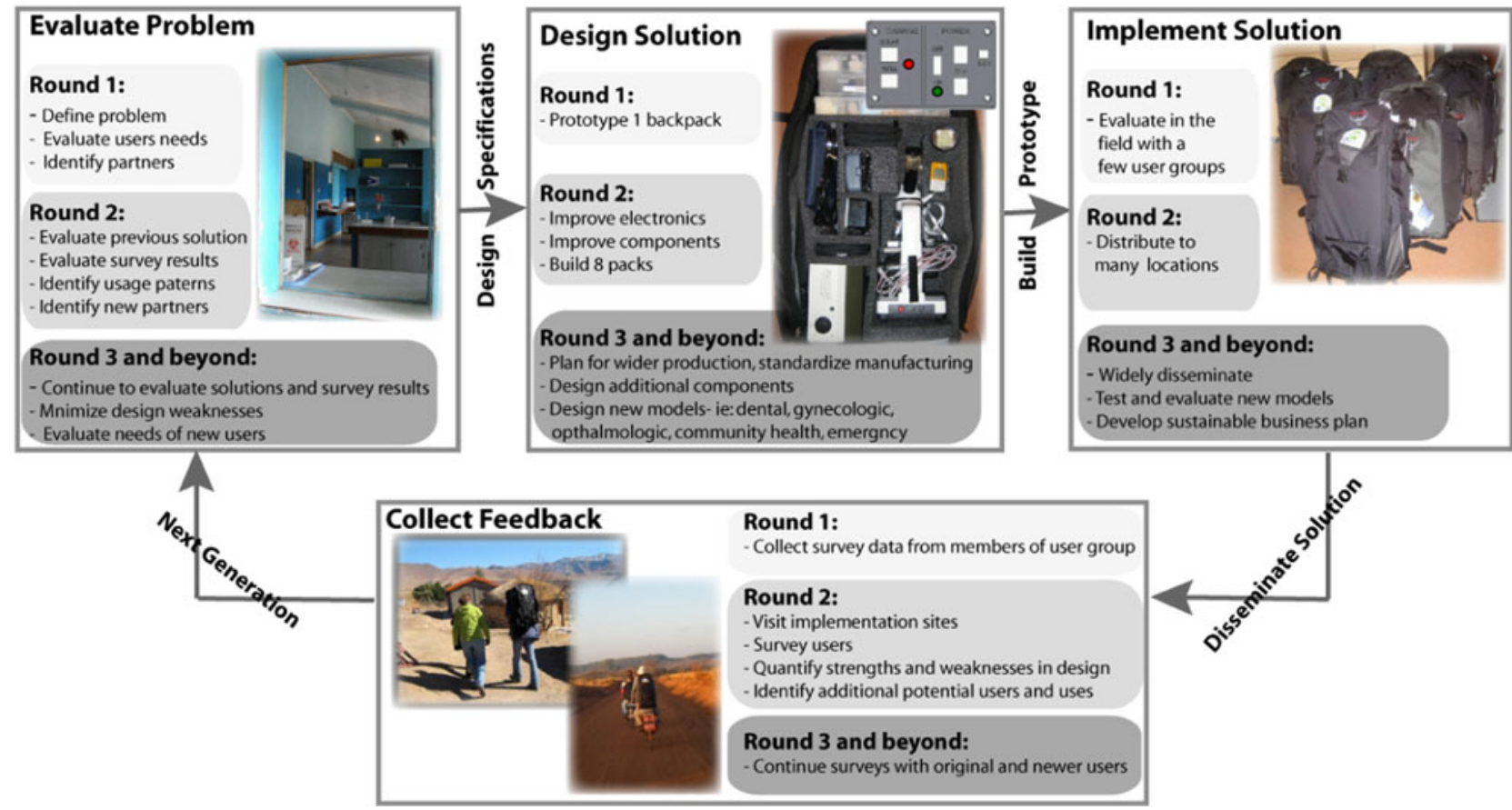

FIGURE 1. Teams of students collaborate to use the engineering design process to evaluate problems, design, and implement solutions. Over several years, 13 students designed and refined a Diagnostic Lab-in-a-Backpack to improve health care in rural settings served by medical brigade teams. The teams cycled through the design process in several rounds, as shown above, improving and refining the pack each time.

officials who have identified pressing areas of need within their own communities. Through these collaborators and venues, a diverse range of student design challenge projects have been identified ${ }^{20}$ (Table 2). New projects are identified and evaluated by interdisciplinary teams of faculty and mentors from multiple disciplines; criteria to evaluate whether potential design challenges are appropriate for undergraduate teams have been developed (Table 3). As students develop solutions for their design problem, the local mentors assist in guiding the process as well as in evaluating how effective the solution might be for their own environment.

\section{INTERNSHIPS TO IMPLEMENT STUDENT-DESIGNED SOLUTIONS}

To further their engagement in learning, students who have participated in a project-based course can participate in summer internships to implement the solutions they have designed. During the internship, students are given three tasks. The first is to test and implement their solution; the second is to develop a solution to a global health challenge designated by their host mentors; and the third is to identify a project on their own and develop a locally acceptable and sustainable solution. Through these activities, student-designed solutions have begun to reach large numbers of clients (Fig. 2). Three examples illustrate the range of activities students have undertaken.

\section{Diagnostic Lab-in-a-Backpack}

$70 \%$ of people in sub-Saharan Africa live in rural areas ${ }^{17}$ while the majority of their healthcare facilities are in urban areas; physicians leading medical brigades to rural areas identified lack of diagnostic tools as a barrier to providing effective health care. In response to the challenge provided by these physicians, students designed a backpack for health providers working in rural areas; the backpack contains tools to diagnose major health issues in these regions (Fig. 1). Students established design criteria through surveys and interviews of health care providers working in developing countries. They designed packaging and control electronics to meet cost, size, and weight specifications. Tools in the backpack include a $100 \times$ oil immersion microscope, mini-centrifuge, otoscope, ophthalmoscope, glucometer, pulse oximeter, sphygmomanometer, and several rapid diagnostic tests. Electrical power is supplied from a central control unit, powered by a laptop battery that is recharged via wall power or a portable solar panel included in the backpack. More than 30 physicians have used the backpack to care for approximately 7,200 patients in Honduras, Haiti, 
TABLE 2. Example design projects in the rice university global health technologies minor.

Global health technologies

Pictorial Dosing Guides

Medication Adherence Measurement

Medicine Dosing Device

Low-Power Medicine Refrigeration Device

IV Fluid Production System

Diagnostic Lab-in-a Backpack and Backpack Suite

IV Drip Monitor

Portable Optical Immunoassay System

Low-cost Phototherapy Lights

Portable Low Power Pulse Oximeter

Portable Field Microscope

Warming Crib

Oxygen Sensor and Flowmeter
Students designed an interactive software program to produce a pictorial guide to help patients adhere to a complex daily anti-HIV drug regimen. The program was tested and implemented in a pediatric AIDS clinic in Botswana. Another team developed medication dosing guides for a health clinic in a low resource immigrant clinic in Houston

Students designed a method for pharmacists to accurately assess a patient's adherence to their HIV treatment program by quickly measuring how much medication has been used between clinic visits. The method was implemented in Lesotho and Swaziland. The system was also adapted to rapidly dispense medications

A team of students designed an easy-to-manufacture syringe insert to provide accurate doses of liquid medicine for patients who are unable to accurately measure prescribed doses. A patent application has been filed and field testing will occur Summer 2010

Students designed a portable refrigeration device to keep medicines cool with minimal power requirements. We are working with the Houston Public Health Department to use the device in city ambulances. The project received a Houston Society for Engineering in Medicine and Biology (HSEMB) Student Design Showcase Second Place Award 2007. A patent application has been filed

Students designed a portable IV fluid production system that can take clean water and produce sterile IV fluid. The project received a NASA Texas Space Grant Consortium (TSGC) Presentation Award 2006-2007

Students designed a portable diagnostic lab in a backpack for health care workers to carry essential diagnostic equipment to remote areas. The backpack was field tested by physicians in Honduras, Nicaragua, Ecuador, Dominican Republic, Guatemala, Haiti, Peru, Tanzania, Botswana, Lesotho, Malawi, Swaziland, and Myanmar. Subsequently, additional teams of students designed field tested backpacks for the following specialized uses: OB/GYN, Community Health Officer, Dental, and Eye Care Packs

Students designed a battery powered, clip-on IV drip monitor to display, monitor and control the flow rate of IV fluids from gravity fed IV bags to avoid over hydration-particularly in pediatric patients for use in a government hospital in Lilongwe, Malawi. The project won second Place Student Design Project, HSEMB in February 2008

Students built a portable tool that can detect disease in whole blood without requiring the expensive and technology intensive processing that is normally associated with ELISA immunoassays. This device uses nanoshell technology and relatively inexpensive optical components. This project received the Top Design Project Award, NASA TSGC Fall 2007 and Spring 2008

Students designed a low-cost, LED based set of phototherapy lights to treat neonatal jaundice for incubators in the neonatal intensive care unit at the Queen Elizabeth Central Hospital in Blantyre, Malawi. Sixteen sets of phototherapy lights have been provided to hospitals in Malawi, Lesotho, Swaziland, and Nicaragua

Students designed a portable pulse oximeter that requires minimal power, works in pediatric patients and can be stored by a physician as a personal tool for use in a government hospital in Gabarone, Botswana. The team won first Place Student Design Project, HSEMB in February 2008

A student designed, prototyped, and successfully validated a battery-powered fluorescence microscope against conventional microscopes for the detection of tuberculosis and malaria in point-of-care settings. This project won the Rice School of Engineering Best Design Project of 2008-2009

Students modified an existing warming crib used in Queen Elizabeth Central Hospital in Blantyre, Malawi to incorporate safety features such as temperature regulation and standardized electronic components. Seven warming cribs are being evaluated at hospitals in Lesotho, Malawi, Swaziland, and Nicaragua

Students designed a low-cost battery-operated device for the measurement of oxygen concentration and flowrate from available oxygen concentrators or tanks in clinic hospitals. The oxygen sensor and flowmeter is currently undergoing field testing at Galmi Hospital in Niger, as well as hospitals in Lesotho and Malawi
Dominican Republic, Guatemala, Nicaragua, Ecuador, Peru, Lesotho, Botswana, Malawi, Swaziland, Tanzania, and Myanmar. These users have relayed valuable feedback to students, allowing them to develop second and third generation backpacks. We are currently working with an NGO in Houston, Medical Bridges, which provides medical supplies to clinics in the developing world, to manufacture and 
TABLE 3. Criteria for successful design challenges.

\begin{tabular}{|c|c|c|c|}
\hline \multicolumn{2}{|l|}{ Global health design project decision matrix } & \multicolumn{2}{|c|}{ (insert project name here) } \\
\hline & Weight (\%) & $\begin{array}{c}\text { Rating } \\
\text { (on a scale of } 0 \text { to } 5 \text { ) }\end{array}$ & $\begin{array}{c}\text { Score } \\
(\text { wt } \times \text { rating })\end{array}$ \\
\hline \multicolumn{4}{|l|}{ Step 1: Is a commercially available, appropriate solution already available? } \\
\hline \multicolumn{4}{|l|}{ If no...Step 2: Assess the proposed project against the following criteria } \\
\hline \multicolumn{4}{|c|}{ Ratings Categories: $0=\mathrm{n} / \mathrm{a}, 1=$ poor, $2=$ fair, $3=$ average, $4=$ good, $5=$ excellent } \\
\hline \multicolumn{4}{|l|}{ Design project factors } \\
\hline Alignment with significant community need & 15 & & 0 \\
\hline Alignment with recognized global healthcare/education challenge & 15 & & 0 \\
\hline Appropriate level of difficulty for undergraduate students & 15 & & 0 \\
\hline $\begin{array}{l}\text { Appropriate expertise \& resources are available to support project } \\
\text { development \& prototyping }\end{array}$ & 15 & & 0 \\
\hline $\begin{array}{l}\text { Realistic project \& prototype completion/advancement } \\
\text { within } 1-2 \text { semesters }\end{array}$ & 10 & & 0 \\
\hline \multicolumn{4}{|l|}{ For potential target communities } \\
\hline Clear understanding of current practices to address need & 10 & & 0 \\
\hline Clear understanding of current difficulty/bottlenecks to meeting the need & 10 & & 0 \\
\hline \multirow{2}{*}{$\begin{array}{l}\text { Clear understanding of new solution constraints } \\
\text { (i.e., infrastructural, cultural, environmental) }\end{array}$} & 10 & & 0 \\
\hline & & Total (out of 5 ) & 0 \\
\hline \multicolumn{4}{|l|}{ Development \& implementation factors } \\
\hline Quality/Responsiveness of Houston-based Mentor(s) & 15 & & 0 \\
\hline Quality/Responsiveness of On-site Mentor(s) & 15 & & 0 \\
\hline Quality of On-site Clinic/Institution/School (e.g., facilities \& staff) & 15 & & 0 \\
\hline Local Interest in/Commitment to Project Implementation & 15 & & 0 \\
\hline Project Scale-up Potential in the community & 10 & & 0 \\
\hline Project Impact Potential in the community & 10 & & 0 \\
\hline Scale-up/Impact Potential at the national level & 10 & & 0 \\
\hline \multirow[t]{3}{*}{ Scale-up/Impact Potential at the international level } & 10 & & 0 \\
\hline & & Total (out of 5 ) & 0 \\
\hline & & Overall score (out of 10 ) & 0 \\
\hline
\end{tabular}

distribute larger numbers of the Diagnostic Lab-in-aBackpack. Through this collaboration, BTB students produced 24 packs recently delivered to the Ministry of Health in Ecuador, representing the first countrywide scale-up of a BTB student-led intervention. In 2010, it is estimated the packs will be used to help provide healthcare to more than 120,000 patients.

\section{Intravenous Drip Monitor}

Hospitals in developing countries struggle to provide care because they are often understaffed and lack modern equipment. Pediatricians working in these hospitals identified the danger of providing intravenous therapy to dehydrated children in such settings as a significant challenge. Intravenous delivery of fluid can be a lifesaving therapy for severe dehydration, but without a safe and effective electronic monitoring system or adequate nursing care, pediatric patients risk fluid overload, which can lead to death. In response to this challenge, a team of bioengineering and electrical engineering students designed a low-cost, batterypowered device to monitor and control the rate and volume of fluid delivered, and to shut down and alert hospital staff when pediatric patients have received sufficient fluid. The device was designed to use minimal power, clip directly onto the existing IV drip chamber, and control and monitor flow rate, time, and volume as set by a clinician. It is able to deliver flow rates of up to $100 \mathrm{~mL} / \mathrm{h}$ at an accuracy of $\pm 1 \%$. The design criteria and solution were both critically evaluated by several physicians in the developing world to ensure that the final device met their needs. A prototype device has been laboratory tested for accuracy and reliability (Fig. 3), and is undergoing revision prior to initial field testing in clinics in sub-Saharan Africa.

\section{Liquid Medication Dosing Device: Accurate Dosing of Liquid Medications to Pediatric Patients is a Global Challenge}

Physicians prescribing liquid anti-retroviral medications to HIV-infected children in developing countries expressed the need for a simple device that could be pre-set by a pharmacist to deliver only the correct dosage of medicine each time without regard to a caregiver's literacy, visual acuity, or manual dexterity. In response, a team of senior bioengineering design 
Annual Student Participation

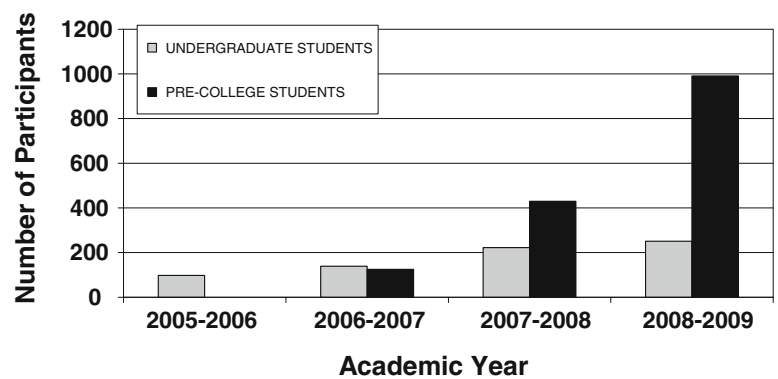

Annual Number of Clients Served

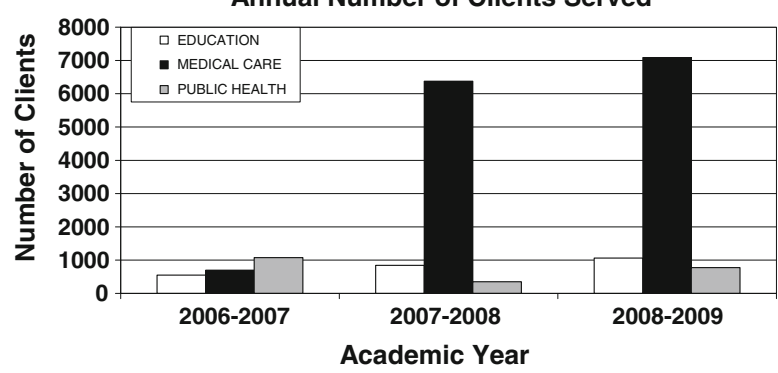

FIGURE 2. (Top) Numbers of students participating in the global health technologies program at Rice University over time. (Bottom) Numbers of clients served by design projects in the global health technologies program at Rice University over time. students designed a mechanical, metered dosing pump for liquid medications (Fig. 4, left). The spring-loaded pump is designed to screw onto the top of a bottle of liquid medication. The pharmacist installs a stop which controls the depth to which the pump can be depressed. Depressing the pump fully compresses the spring to the desired length; as the spring expands, medication fills the dosing chamber with the correct dosage of medicine. Depressing the pump a second time dispenses the proper dose of medication into a cup for the patient. While this design met the design criteria, feedback from pediatricians and pharmacists working in the United States, Botswana, Malawi, and Rwanda identified several significant challenges. It was difficult to set the dosage to the correct value, it was difficult to assemble the pump, it was difficult to clean the pump, and the estimated cost of approximately $\$ 1$ per pump was too high. In response, a second team of entry-level design students was presented with the design challenge, and feedback received regarding the initial design. They designed a much simpler solution (Fig. 4, right), which consists of a plastic clip that can be placed in a standard oral dosing syringe to limit the distance the plunger can be pulled back. The length of the clip dictates the amount of fluid that can be
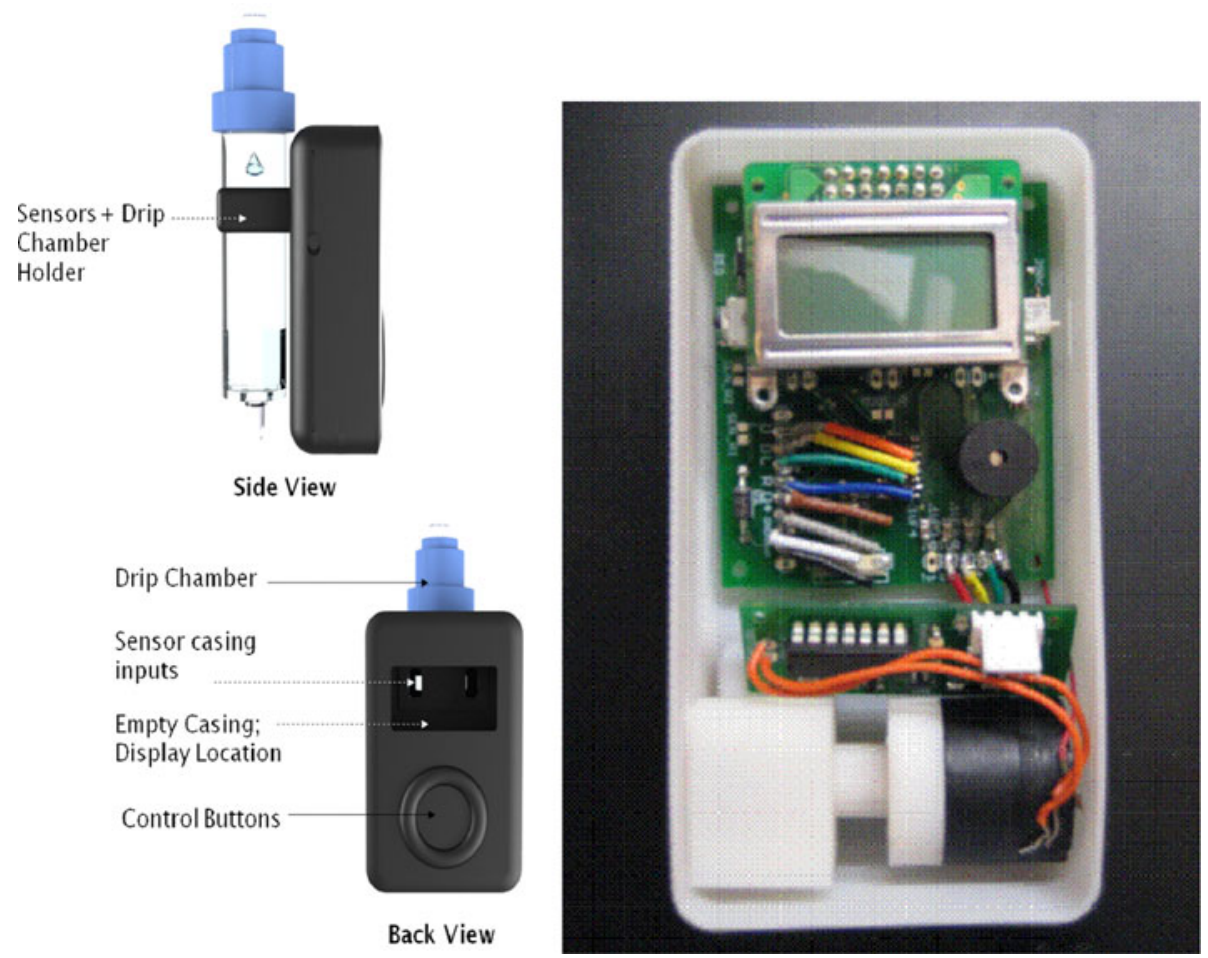

FIGURE 3. Prototype battery powered IV drip monitor. 

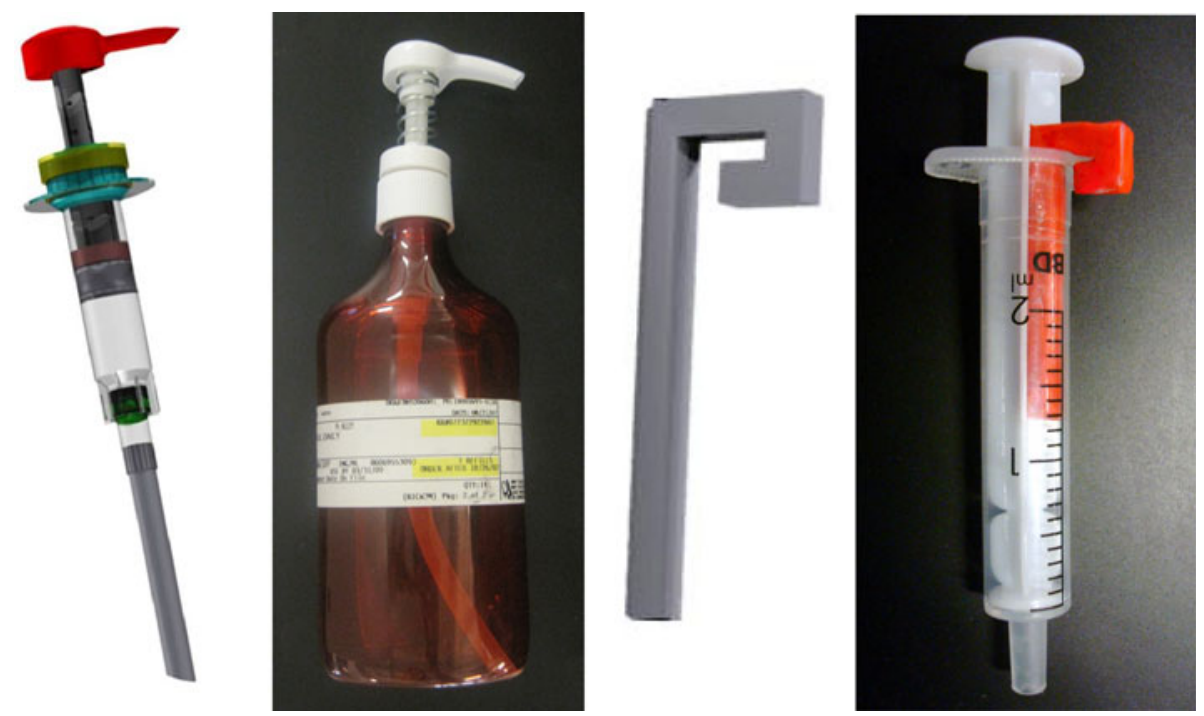

FIGURE 4. Solutions for accurate dosing of liquid medications. Dosing pump shown on left and syringe clip shown on right.

drawn into the syringe. The clip does not come in contact with medication, it can be quickly and easily affixed by a health care professional, and can be manufactured for $<\$ 0.10$. While the dosing accuracy of the two prototype solutions shown in Fig. 4 is similar, feedback from potential users in the field indicates that the second iteration is greatly preferred.

\section{Dissemination and Education}

Even when appropriate technology solutions are available, developing sustainable approaches to disseminate these solutions in resource-poor environments remains difficult. Entrepreneurs in developing countries often face challenges in supply chain management resulting from a lack of infrastructure, and have difficulty securing investment capital. Indeed, many administrators at partner secondary schools in developing countries identified the lack of educational materials concerning entrepreneurship as an important educational need for their students. Such educational challenges can be used as the basis of design projects. For example, when undergraduate students use the engineering process to design micro-enterprise educational programs, it not only helps meet educational needs in the developing world, but also helps them appreciate the challenges of sustainable dissemination and prepares them to help develop enterprise-based solutions of their own. In one program, undergraduates worked with teachers at partner schools and university faculty to define and prioritize entrepreneurship learning objectives and to delineate resource constraints. To meet these learning objectives in the face of local barriers, they designed a micro-enterprise training program for secondary school students; materials were implemented in a 4-week course for high school students near Maseru, Lesotho. The course covered leadership and teamwork, marketing, evaluating business potential, accounting and book-keeping, and business planning. Students in the undergraduate intern-led course engaged in active learning in each unit, and worked as a class to sell solar-powered flashlights to raise capital for a cooperative business. The school designated space for a new cooperative business, a small shop that sells food and other small consumer items. The class elected four of their peers to manage the shop, which ran successfully for more than 24 weeks. Students in the course also developed business plans for individual enterprises. Students identified food insecurity as an important issue; interns worked with the students to build a school garden, with the produce to be sold in the school's store. Students participating in the course ranked activities involving active learning as particularly valuable, with an average of 4.52 on a Likert-scale ranging from a low of 1 to a high of 5 (Table 4).

Similarly, using this approach to develop public health education materials can effectively engage lower level undergraduates from a broad range of disciplines in the process of design. Interns designed and taught HIV/AIDS education to a group of middle-school aged orphans in sub-Saharan Africa. Student knowledge about HIV/AIDS increased from 49 to $70 \%$ as assessed by a pre- and post-test. Another group of student interns designed and implemented a program to teach over 450 Haitian elementary students and their parents about the importance of drinking clean water and nutrition; knowledge increased from 69 to $86 \%$ as assessed by a pre- and post-test. This educational program was developed in collaboration with over 
TABLE 4. Student evaluation of micro-enterprise training course.

\begin{tabular}{lc}
\hline Activity & $\begin{array}{c}\text { Average student } \\
\text { ranking scale of } \\
1 \text { (low) to 5 (high) }\end{array}$ \\
\hline Teamwork and leadership & 4.8 \\
Marketing exercise & 4.29 \\
Business plan development & 4.97 \\
Bookkeeping & 4.55 \\
Problem of the day & 4.32 \\
Selling flashlights & 4.52 \\
Guest lecture-Boliba savings and credit & 4.4 \\
Guest lecture-Telajane society & 4.36 \\
Market research trip & 4.55 \\
\hline
\end{tabular}

15 Haitian elementary school teachers and administrators who have now assumed responsibility for the curriculum and continue teaching new groups of students.

\section{Global Health Technology Dissemination}

In order to explore the challenges and importance of appropriate business models for wide scale dissemination of the technologies that have been developed as part of the BTB program the class "Commercializing Technologies in the Developing World" was developed. MBA and senior-level undergraduate engineering students work in interdisciplinary teams to write business plans for select global health technologies developed by students in the undergraduate minor in global health technologies. Technologies in the class have included a suite of medical backpacks, including the Lab-in-a-Backpack, obstetric/gynecology, dental, eye care, and community health outreach packs; the IV-drip monitor to safely and accurately deliver IV fluid to children; a continuous positive airway pressure machine for neonates; a low cost incubator and phototherapy lights and the oral dosing syringe to accurately dispense liquid medication.

Engineering students on the commercialization teams provide expertise about technology design to facilitate rapid integration of consumer demand into product design. MBA students apply their management skills to develop sustainable models of dissemination. This partnership helps MBA students understand the technical constraints and possibilities of the technologies; at the same time, engineering students learn how the commercialization process influences appropriate technology design.

In the first half of the course, student teams learn about commerce-based models for delivering goods and services in the developing world. They develop printed marketing materials and refine their elevator pitches for their products. Over spring break, students travel to Rwanda to gather feedback from a range of experts on the design of the technologies and do field research for their business plans. The students meet with local manufacturers and distributors, government officials, healthcare providers, regulatory agency representatives, non-governmental organizations, and entrepreneurs. They visit urban and rural healthcare facilities and local manufacturing facilities, and gather information on consumers, users, market size, manufacturing options, local businesses, and pricing. The students then spend the second half of the course writing their business plans, which they present to potential investors and other stakeholders at a public event.

\section{IMPACT OF BIOENGINEERING PROJECT-BASED GLOBAL HEALTH EDUCATION}

Since 2006, over 333 Rice University students, more than $10 \%$ of undergraduate students at Rice, have participated in a BTB global health technology course and completed a design project. Students have designed 40 new interventions (Fig. 2). Twenty-eight of these designs have been used in 15 international healthcare settings, including in sub-Saharan Africa, Latin America and the Caribbean, and Southeast Asia, and have touched the lives of nearly 18,000 people. Students have collaborated with 153 mentors, representing 52 institutions in 15 countries. The multi-disciplinary nature of the minor has attracted a broad group of students, including those majoring in bioengineering $(17 \%)$, other engineering disciplines $(4 \%)$, natural sciences $(18 \%)$, social sciences $(27 \%)$, and humanities $(33 \%)$, creating a group of students with varied skill sets and a broad knowledge base.

Science and engineering majors learn to use an expanded perspective in the process of developing solutions to health technology challenges, whereas non-science majors learn about global health problems and participate in technology design when previously they would have had little exposure to the field or opportunity to contribute to global health solutions through the lens of bioengineering. A focus on alleviating disparity also provides an opportunity to increase the diversity of students studying science; $66 \%$ of students in the program were female and $11 \%$ were under-represented minorities. Research indicates that for women and minority students, the study of science is made meaningful by connections to other fields. ${ }^{14}$

Students participating in the entry- and senior-level global health technology design courses were surveyed in Spring 2008 to assess whether the course project enhanced their skills. Results for global health technology courses were compared to those for other 
courses at Rice University with a civic research and design project. A total of 137 students were surveyed, including 47 students enrolled in global health technology design courses. A greater fraction of global health technology students reported that the course project enhanced skills in the following areas: creativity ( $60 \%$ global health; $28 \%$ other programs); leadership ( $78 \%$ global health; $44 \%$ other programs); ability to affect social change $(60 \%$ global health; $40 \%$ other programs); ability to solve real-world problems ( $94 \%$ global health; $76 \%$ other programs).

Students who completed an international internship were surveyed to assess the impact of the program on their educational and career goals. Results indicate that the internship had a particularly strong impact on participants' career intentions. After the experience, $32 \%$ of interns reported that they shifted their engineering/science/policy career plans to include a primary focus on global health. $42 \%$ of interns reported that they plan to include an international health component in their MD or other health-related career plans. Finally, $21 \%$ of students reported that, while they had been uncertain of their career plans before the internship, they now plan to pursue careers in global health. As one student said, "Prior to my experiences with BTB, I had a very narrow view of work opportunities in health. I was able to see the inter-disciplinary nature of global health problems and was drawn to the complex technical, social, political, and economic factors that play a role in global health."

As foreign policy is increasingly driven by global health issues, ${ }^{11}$ it is imperative to develop future global health leaders with expertise in a broad range of disciplines, including engineering, economics, political science, and sociology. Undergraduate educational programs offer an ideal opportunity to motivate and educate future leaders who can develop and implement innovative solutions to the diverse challenges of global health. Because of its multi-disciplinary, designcentered nature, the field of Biomedical Engineering should take a leadership role in meeting this educational challenge. Engaging university students in the practice of engineering design to solve difficult health challenges strengthens these fields with passionate, dedicated, and diverse leaders, and can improve the health of people in the United States and around the world.

\section{ACKNOWLEDGMENTS}

The Beyond Traditional Borders initiative is made possible by a grant to Rice University from the Howard Hughes Medical Institute through the Undergraduate Science Education Program.
Beyond Traditional Borders gratefully acknowledges contributions of the following organizations: the Rice University Center for Civic Engagement, the Baylor International Pediatric AIDS Initiative, the Baylor Shoulder to Shoulder Foundation, Bethlehem Ministries, Faith in Practice, the Futuro Foundation, Medical Bridges, MLO the Cooperative-Nicaragua, Operation San Andres, the PAHO/WHO Center for Training in International Health at UT Medical Branch Galveston, Partners for Rural Health in the Dominican Republic, Partners in Health, Project Medishare, the Shanta Foundation, St. Gabriel's Hospital-Namitete, Malawi, The Luke Commission-Swaziland, and Village Life Outreach Project.

\section{OPEN ACCESS}

This article is distributed under the terms of the Creative Commons Attribution Noncommercial License which permits any noncommercial use, distribution, and reproduction in any medium, provided the original author(s) and source are credited.

\section{REFERENCES}

${ }^{1}$ Amadei, B. Engineering for the developing world. Bridge 34:24-31, 2004.

${ }^{2}$ Barbiero, V. K. Global health for undergraduates - "We Are Not Alone". Am. J. Prev. Med. 35:269-272, 2008.

${ }^{3}$ Bransford, J. D., A. L. Brown, and R. R. Cocking (eds.). How People Learn, Brain, Mind, Experience, and School. Washington, DC: National Academy Press, 1999.

${ }^{4}$ Cashman, S. B., and S. D. Seifer. Service-learning: an integral part of undergraduate public health. Am. J. Prev. Med. 35:273-278, 2008.

${ }^{5}$ Commission on Social Determinants of Health. Closing the Gap in a Generation: Health Equity through Action on the Social Determinants of Health. Geneva: World Health Organization, 2008.

${ }^{6}$ Drain, P. K., A. Primack, D. D. Hunt, W. W. Fawzi, K. K. Holmes, and P. Gardner. Global health in medical education: a call for more training and opportunities. Acad. Med. 82:226-230, 2007.

${ }^{7}$ Gebbie, K., L. Rosenstock, and L. M. Hernandez (eds.). Who Will Keep the Public Healthy? Educating Public Health Professionals for the 21st Century. Washington, DC: National Academy Press, 2003.

${ }^{8}$ Hotez, P. J. Training the next generation of global health scientists: a school of appropriate technology for global health. PLoS Negl. Trop. Dis. 2(8):e279, 2008. doi: 10.1371/journal.pntd.0000279.

${ }^{9}$ Izadnegahdar, R., et al. Global health in Canadian medical education: current practices and opportunities. Acad. Med. 83:192-198, 2008.

${ }^{10}$ Jamison, D. T. (ed.). Disease Control Priorities in Developing Countries. New York: Oxford University Press and the World Bank, 2006. 
${ }^{11}$ Kickbusch, T., E. Novotny, N. Drager, G. Silberschmidt, and S. Alcarzar, Global health diplomacy: training across disciplines. Bull. World Health Organ. 85:971-973, 2007.

${ }^{12}$ Madon, T., K. J. Hofman, L. Kupfer, and R. I. Glass. Public health: implementation science. Science 318:17281729, 2007.

${ }^{13}$ Malkin, R. A. Design of health care technologies for the developing world. Annu. Rev. Biomed. Eng. 9:567-587, 2007.

${ }^{14}$ Margolis, J., and A. Fisher. Unlocking the Clubhouse, Women in Computing. Cambridge, MA: MIT Press, 2001.

${ }^{15}$ McKinley, D. W., S. R. Williams, J. J. Norcini, and M. B. Anderson. International exchange programs and U.S. medical schools. Acad. Med. 83:S53-S57, 2008.
${ }^{16}$ Petrakova, A., and R. Sadana. Problems and progress in public health education. Bull. World Health Organ. 85:963970, 2007.

${ }^{17}$ Population Division of the Department of Economic and Social Affairs of the United Nations Secretariat. World Population Prospects: The 2006 Revision and World Urbanization Prospects: The 2007 Revision. http://esa.un. org/unup/.

${ }^{18}$ Riegelman, R. K. Undergraduate public health education: past, present, and future. Am. J. Prev. Med. 35:258-263, 2008.

${ }^{19}$ Sadana, R., and A. Petrakova. Shaping public health education around the world to address health challenges in the coming decades. Bull. World Health Organ. 85:902-903, 2007.

${ }^{20}$ www.beyondtraditionalborders.rice.edu. 